\title{
Sweetened Condensed Consumption of more than 1 Glass per Day Has an Impact on Underweight Among Children under Age Five
}

\author{
Tria Astika Endah Permatasari ${ }^{*}$, Yudi Chadirin ${ }^{2}$ \\ ${ }^{1}$ Nutrition Program Study, Faculty of Medicine and Health, Universitas Muhammadiyah Jakarta, Jakarta, Indonesia \\ ${ }^{2}$ Department of Civil and Environmental Engineering, Bogor Agricultural University, Bogor, Indonesia \\ *Corresponding Author. Email: astika.tria@gmail.com
}

\begin{abstract}
Sweetened condensed contains high sugar which has a negative impact on the children's health. The purpose of this study was to analyze the relationship of sweetened condensed consumption and other factors on underweight among children under age five. A cross-sectional study was conducted in January-March 2019. A total of 122 children 0-59 months met inclusion criteria in Caringin Public Health Center area, Bogor district, Indonesia. Underweight is measured by anthropometry (weight-for-age based on WHO Child Growth Standards). Sweetened condensed consumption was assessed using the Food Formulir Questionnaire (FFQ). Most children consume sweetened condensed creamer more than 1 glass per day (80.3\%), $22.1 \%$ underweight and $4.1 \%$ severe underweight. Multiple logistic regression analysis shows that sweetened condensed creamer consumption is the most dominant variable affecting underweight among children under age five $(\mathrm{OR}=3.172$; 1.011-9.958, 95\% CI). Protein and energy consumption, drinking water treatment, and infectious diseases also significantly affecting underweight among children under five. Children who consumed sweetened condensed creamer more than 1 glass per day 3,172 times higher risk of underweight compared to children who consumed less than that amount. Supervision is indispensable to the policy implementation of restrictions on the sweetened condensed creamer consumption among children under age five.
\end{abstract}

Keywords: sweetened condensed creamer, children under age five, underweight

\section{INTRODUCTION}

Malnourished children have a higher risk of death from common childhood illnesses. Nutrition-related factors contribute to about $45 \%$ of deaths in children under age five in the world [1]. Underweight is one of growth indicators that an indicator that shows fewer children weight based on age (weight-for-age $<-2$ standard deviations (SD) of the WHO Child Growth Standards median). Being underweight may also reflect wasting (low weight-for-height ratio) and or stunting (low height-for-age ratio) [1-2]. Children who are underweight are lack of micro and macronutrients that are required for proper optimum growth. Underweight puts children at greater risk of dying from common infections. It also has adverse with impaired cognitive ability, reduced school and work performance, and less psychosocial development [3-5].

Underweight is a global public health problem. In 2011, an estimated 101 million children under 5 years were underweight. Worldwide, childhood prevalence was decline from around $27 \%$ in 1990 to $18 \%$ in 2015 . This number is also declining in many developing countries [6]. A cross-sectional study using Multiple Indicators Cluster
Survey 2012-2013 in Bangladesh data on 17,133 children under 5 years of age shows that an estimated $31.67 \%$ of children were underweight and $8.81 \%$ of children were severely underweight [7]. Another similar study using a community based cross-sectional study at Takusa district, northwest Ethiopia shows from 645 children, the overall prevalence of underweight was $19.5 \%$ (95\% CI: 16.4-22.8) [8]. Another research in Punjab province, Pakistan among 24042 children under 5 years of age shows that the prevalence of moderately and severely underweight children was $33.3 \%$ and $11.3 \%$, respectively [9].

In Indonesia according to data of Basic Health Research (Ministry of Health), the number of underweight children under age five decrease slowly from $19.6 \%$ (2013) to $17.5 \%$ (2018) [10]. One of the provinces that has the highest prevalence of under nutrition is West Java, with one of the highest contributors is from Bogor district particularly of stunting incidence. Whereas for underweight, the prevalence of childhood underweight in West Java lower than other provinces in this country (around 14\% in 2018), but still categorized as moderate prevalence according to cut-off values for public health significance by WHO. 
Underweight of children under five years is caused by the interaction of many factors, especially food intake and infectious diseases as direct causes. Other factors that indirectly affect underweight are household food security, maternal and child care, health services and the environment [1]. Generally in developing countries, the incidence of caused by low socioeconomic. A previous study among 3071 Pakistani children aged 0-59 months from the PDHS 2012-2013 shows that 29.4\% were underweight. This incidence maternal-socio-demographic and child-level variables such as recent diarrheal incidence and breastfeeding status. Poverty, illiteracy, unavailability of food, location and proximity to procure food, lack of physical activity, poor sanitation and hygiene were the contributors to the poor nutritional status [11].

Sweetened condensed, or also known as Sweetened Condensed Milk is suspected of not containing milk and isn't suitable for consumption by children. It made from raw milk, brownish-white, thick, and feels sweet but, it isn't milk. This is not a guess, but an explanation of the product that is currently being discussed. The product that has been known by the public as Sweetened Condensed Milk (SCM), it turns out cannot be called milk [12]. The BPOM instructed that sweetened condensed milk not be marketed as other types of milk, such as fresh milk, pasteurized milk, sterilized milk, formula milk, and fortified milk. It stated that sweetened condensed milk should not project images of children under five years old, images of fresh milk and images of milk in a glass [13]. In the lower socioeconomic community, consumption of sweetened condensed creamer is considered to have met the nutritional needs of children under age five. The purpose of this study was to analyze the relationship of sweetened condensed consumption and other factors on underweight among children under age five.

\section{METHODS}

A cross sectional study was conducted in January-March 2019. A total of 122 children 0-59 months met inclusion criteria in Caringin Public Health Center area, Bogor district, Indonesia. Underweight is measured by anthropometry (weight-for-age based on WHO Child Growth Standards). Sweetened condensed consumption as independent variables was assessed using Food Formulir Questionnaire (FFQ). Another independent variables are protein and energy consumption, drinking water treatment, and history of infectious diseases (diarrhea and acute respiratory infection), history of immunization, breastfeeding, and maternal-social-demographic (age, education), and mother's knowledge about nutrition. All independent variables were measured primarily using structured questionnaire by interview techniques. This study has obtained an ethical qualification letter from the Health Research Ethics Commission of the Faculty of Medicine and Health, Universitas Muhammadiyah Jakarta with the number 001 / PE / KE / FKK-UMJ / I / 2019.

\section{RESULTS AND DISCUSSION}

\section{Respondent Characteristics}

This study was conducted in rural areas in Bogor district, West Java Indonesia. Therefore this region represents the sociodemographic characteristics of the lower socioeconomic community. Table 1 shows that as many as $22.1 \%$ of children under age five suffer from underweight and $4.1 \%$ severe underweight. Children who consumed sweetened condensed creamer $>1$ glass per day were $80.3 \%$. In this study, children have low energy (42.6\%) and protein $(39.3 \%)$ consumption. More than half of mothers serve drinking water directly without cooking (73.8\%). Mothers generally consume drinking water from mountain springs and assess that the water is safe for consumption. Almost as much as $60 \%$ of children under age five have suffered from an infectious disease that is diarrhea and or acute respiratory infection. Almost all children get basic immunization completely $(90.2 \%)$.

Table 1. Respondent Characteristics and Association Sweetened condensed creamer and others factors with underweight among children under age five

\begin{tabular}{|c|c|c|c|c|}
\hline No & Category & Frequency (n) & $\%$ & $\begin{array}{c}\text { p- } \\
\text { value }\end{array}$ \\
\hline \multirow[t]{5}{*}{1.} & \multicolumn{3}{|l|}{ Children Nutritional Status } & \\
\hline & Severe underweight & 5 & 4.1 & 0.000 \\
\hline & Underweight & 27 & 22.1 & \\
\hline & Normal & 87 & 71.3 & \\
\hline & Overweight & 3 & 2.5 & \\
\hline \multirow[t]{3}{*}{2.} & \multicolumn{3}{|c|}{ Sweetened condensed creamer consumption } & \\
\hline & $>1$ glass per day & 98 & 80.3 & 0.001 \\
\hline & $\leq 1$ glass per day & 24 & 19.7 & \\
\hline \multirow[t]{3}{*}{3.} & $\begin{array}{l}\text { Energy consumption } \\
\text { frequency }\end{array}$ & & & \\
\hline & $<3 \mathrm{x} /$ day & 52 & 42.6 & 0.034 \\
\hline & $\geq 3 \mathrm{x} /$ day & 70 & 57.4 & \\
\hline \multirow[t]{3}{*}{4.} & $\begin{array}{l}\text { Protein consumption } \\
\text { frequency }\end{array}$ & & & \\
\hline & $<3 x /$ day & 48 & 39.3 & 0.046 \\
\hline & $\geq 3 \mathrm{x} /$ day & 74 & 60.7 & \\
\hline \multirow[t]{3}{*}{5.} & Drinking water treatment & & & \\
\hline & Drink directly & 90 & 73.8 & 0.028 \\
\hline & cooked & 32 & 26.2 & \\
\hline \multirow[t]{3}{*}{6.} & $\begin{array}{l}\text { History of infectious } \\
\text { disease } \\
\text { (in the past six months) }\end{array}$ & & & \\
\hline & Yes & 72 & 59.0 & 0.036 \\
\hline & No & 50 & 41.0 & \\
\hline \multirow[t]{3}{*}{7.} & History of immunization & & & \\
\hline & incomplete & 12 & 9.8 & 0.510 \\
\hline & complete & 110 & 90.2 & \\
\hline \multirow[t]{3}{*}{8.} & Breastfeeding & & & \\
\hline & $\begin{array}{l}\text { Non-exclusive } \\
\text { breastfeeding }\end{array}$ & 105 & 86.1 & 0.260 \\
\hline & Exclusive breastfeeding & 17 & 13.9 & \\
\hline \multirow[t]{3}{*}{9.} & Age & & & \\
\hline & $<30$ years & 65 & 53.3 & 0.148 \\
\hline & $\geq 30$ years & 57 & 46.7 & \\
\hline
\end{tabular}




\begin{tabular}{|c|c|c|c|c|}
\hline \multirow[t]{3}{*}{10.} & Education & & & \multirow[b]{2}{*}{0.46} \\
\hline & $\begin{array}{l}\text { Low education } \\
\text { (elementary-junior high }\end{array}$ & 78 & 63.9 & \\
\hline & $\begin{array}{l}\text { school) } \\
\text { Higher education } \\
\text { (senior high school) }\end{array}$ & 44 & 36.1 & \\
\hline \multirow[t]{3}{*}{11.} & Mother's knowledge & & & \\
\hline & Lack of knowledge & 92 & 75.4 & 0.08 \\
\hline & Quite good & 30 & 24.6 & \\
\hline \multirow[t]{3}{*}{12.} & Family income & & & \\
\hline & $\begin{array}{l}\text { Low income }(<\text { regional } \\
\text { minimum wage })\end{array}$ & 110 & 90.2 & 0.471 \\
\hline & $\begin{array}{l}\text { High income ( } \geq \text { regional } \\
\text { minimum wage) }\end{array}$ & 12 & 9.8 & \\
\hline
\end{tabular}

Table 1 shows that most children do not get breastfeeding exclusively (86.1\%). In this study, from 122 mothers more than half were $<30$ years old $(53.3 \%)$. Mothers who have quite good knowledge only $24.6 \%$ and almost all mothers have low-income $(90.2 \%)$ that less than district minimum wage based on Central Bureau of Statistics data (2019).

Table 2 shows the results of the final model of multiple regression logistic analysis. There are 5 (five) variables that have a significant association with underweight among children under age five (sweetened condensed creamer consumption, energy consumption frequency, protein consumption frequency, drinking water treatment, and history of infectious disease. From 5 (five) variables, sweetened condensed creamer was the most dominant variable affecting underweight among children under age five $(\mathrm{OR}=3.172 ; 1.011-9.958,95 \% \mathrm{CI})$. Children who consumed sweetened condensed creamer more than 1 glass per day 3,172 times higher risk of underweight compared to children who consumed less than that amount.

Table 2. Multiple Regression Logistic

\begin{tabular}{lccc}
\multicolumn{1}{c}{ Variable } & $\begin{array}{c}\text { P } \\
\text { value }\end{array}$ & OR & 95\% CI \\
\hline Sweetened & 0.000 & 3.172 & $1.011-$ \\
condensed creamer & & & 9.958 \\
$\begin{array}{l}\text { consumption } \\
\text { Protein consumption }\end{array}$ & 0.026 & 2.165 & $1.004-$ \\
frequency & & & 6.642 \\
Energy consumption & 0.042 & 2.014 & $1.114-$ \\
frequency & & & 7.842 \\
$\begin{array}{l}\text { Drinking } \\
\text { treatment water }\end{array}$ & & & $1.125-$ \\
History of infectious & 0.038 & 2.116 & 2.680 \\
diseases & & 2.108 & $1.052-$ \\
\hline
\end{tabular}

Malnutrition including underweight in all its forms is closely linked, either directly or indirectly, to major causes of death and disability worldwide. ${ }^{1}$ In this study, $22.1 \%$ of children under age five suffer from underweight and $4.1 \%$ severe underweight. This number higher than the other study at Takusa district, northwest Ethiopia that shows from 645 children, the overall prevalence of underweight was
19.5\%.8 Although the two research areas show the same thing that is done in the lower economic community, there are differences in eating patterns. In Indonesia, particularly in this study most of the children under age five consumed sweetened condensed $>1$ glass per day $(80.3 \%)$. Sweetened condensed in this study was the most dominant variable affecting underweight among children under age five (OR $=3.172 ; 1.011-9.958,95 \%$ CI). Children who consumed sweetened condensed creamer more than 1 glass per day 3,172 times higher risk of underweight compared to children who consumed less than that amount. Sweetened condensed creamer is the same product as sweetened condensed milk (SCM) except the ingredients frequently contain items other than sugar and milk which may include: vegetable oil (palm oil), whey powder, skim milk powder, maltodextrin, carrageenan, salt, and lactose. However, sweetened condensed milk provides much more sugar than evaporated milk, as some are added during processing [1314].

High sugar content in Sweetened condensed creamer causes negative effects on children's health. High consumption of sugar has led to excessive weight gain and obesity, health problems that are threatening society. But in low socioeconomic families, the sweetened condensed consumption can decrease food intake because they assume that food contains high nutrition. The BPOM instructed that sweetened condensed milk not be marketed as other types of milk, such as fresh milk, pasteurized milk, sterilized milk, formula milk, and fortified milk. Appeals to restrictions on the consumption of sweetened condensed especially the prohibition for infants are stipulated in Perka BPOM No. 31 of 2018 concerning Processed Food Labels related to sweetened condensed creamer or sweetened condensed milk as a Form of Protection for the Community. This regulation was previously informed by the issuance of Circular Letter No. HK.06.5.51.511.05.18.2000 in 2018 concerning Labels and Advertisements on its Condensed Milk and Analog Products (food subcategory 01.3) addressed to all producers/importers/distributors of sweetened condensed creamer.

The circular emphasized that sweetened condensed creamer labels and advertisements should not display children under the age of 5 years and should not be advertised during the children's show airtime. Although most producers have replaced the label Milk with the word Sweetened Condensed Creamer, unfortunately, there are still producers who have not fully implemented this rule. The results of observations in the community show that there are still producers who promote sweetened condensed creamer as milk drinks for parents and children.

Various reasons for parents, especially in rural areas in giving sweetened condensed are based on other facts found in the community, especially in rural areas, parents still provide sweetened condensed creamer as a milk drink for their toddlers for various reasons including that sweetened condensed is indeed milk as they know from TV ads and 
their parents. The prices of sweetened condensed are cheap and children love it because it tastes sweet. It stated that sweetened condensed milk should not project images of children under five years old, images of fresh milk and images of milk in a glass. Moreover, TV commercials of sweetened condensed milk are prohibited from being aired during children's TV programs.

Sweetened condensed creamer is not the only variable that affects underweight among children under age five. The causes of underweight are directly related to inadequate dietary intake as well as disease. The low intake of food in the first 1000 days of a baby's life that starts from exclusive breastfeeding and is continued by feeding complementary feeding until the age of two years is a major cause of underweight in children, both in children who live in rural and urban areas [15]. Where the success of exclusive breastfeeding is influenced by the mother's intention to suckle since the pregnancy period [16]. Besides, children who suffer from infectious diseases such as diarrhea and acute respiratory infections (ARI) are also more at risk for underweight among children under age five that caused by low immunity, personal hygiene, and poor environmental sanitation. Also, it is caused indirectly by many factors including household food security, maternal and child care, health services, and the environment. While most nutrition interventions are delivered through the health sector, nonhealth interventions can also be critical. Actions should target the different causes to reach sustainable change, which requires a multisectoral approach [1-2].

\section{CONCLUSION}

Sweetened condensed was the most dominant variable affecting underweight among children under age five. Children who consumed sweetened condensed more than 1 glass per day 3,172 times higher risk of underweight compared to children who consumed less than that amount. But, sweetened condensed is not the only variable that affects underweight among children under age five. Protein and energy consumption, drinking water treatment, and infectious diseases also significantly affecting underweight among children under five.

\section{RECOMMENDATION}

Supervision is indispensable to the policy implementation of restrictions on the sweetened condensed consumption among children under age five. Promotive and preventive efforts through nutrition education to increase the knowledge of parents, especially mother's knowledge about the negative effect of sweetened condensed consumption are needed to prevent underweight and other nutritional problems among children under age five.

\section{ACKNOWLEDGMENT}

Thanks to the Faculty of Medicine and Health for facilitating this research. Besides, thank you also to the Bogor District Health Office, health workers, enumerators, and cadres who have helped carry out the research.

\section{REFERENCES}

[1] World Health Organization. Manutrition. 2018. www.who.int

[2] World Health Organization. Global Database on Child Growth and Malnutrition. 2018. www.who.int

[3] Telleus GK., et al. Are weight status and cognition associated? an examination of cognitive development in children and adolescents with anorexia nervosa 1year after first hospitalisation. Eur. Eat. Disorders Rev. 24 (2016) 366-376

[4] A. Sadek HA., et al. The relationship between BMI and emotional status of Alexandria university students Egypt. 2016. J Egypt Public Health Assoc. Sep; 91(3):101-108

[5] Golam MD., et al. Prevalence of underweight and effect of nutritional status om academic performance of primary school children in Chapainawabganj district, Bangladesh. 2014. Mal J Nutr 20(1):71-81.

[6] World Health Organization. The global strategy for women's, children's and adolescents' health (2016-2030). 2015. www.who.int

[7] Cowdhury TR., et al. Socio-economic risk factors for early childhood underweight in Bangladesh. Globalization and Health (2018) 14:54, p1-12.

[8] Getnet N., et al. Ptrevalnece and associated factors of underweight among children 6-59 months of age in Takusa district, Northwest Ethiopia. International Journal for Equity in Health (2018) 17:106 https://doi.org/10.1186/s12939-018-0816y. p1-8.

[9] Kumar R., et al. Prevalence and factoirs associated with underweight children: apopulation based subnational analysis form Pakistan. 2019. BMJ Open 2019;9:e028972. doi:10.1136/bmjopen2019-028972.p1-13

[10] Ministry of Health of Indonesia. Basic Health Research years 2018. 2018. Jakarta

[11] Cordelia A., et al. Nutritional status and dietyary intake of semai indigenous children below five years in Perak, Peninsula. 2019. Malaysian Journal of Public Health Medicine 2019, Vol. 19 (1): 84-100.

[12] LPPOM MUI. Sweetened condensed milk is not milk?. 2018. Halalmui.org

[13] Badan POM. The regulation of Sweetened condensed creamer. 2018. Jakarta

[14] Siddique Md. NA., et al. Evaluation of the quality of sweetened condensed milk of different brands available in local markets of Bangladesh. 2017. International Journal of Natural and Social Sciences, 2017, 4(1): 64-70. 
[15] Permatasari TAE and Syafruddin A. Early initiation of breastfeeding related to exclusive breastfeeding and breastfeeding duration in rural and urban areas in Subang, West Java, Indonesia. 2016. J Health Res. 2016; 30(5): 337-345. DOI: 10.14456/jhr.2016.46.

[16] Permatasari TAE, Sartika RAD, Achadi EA, et al. Exclusive Breastfeeding Intention among Pregnant Women. 2018. Kesmas: National Public Health Journal. 2018; 12 (3): 134-141 DOI:10.21109/kesmas.v12i3.1446. 